Supporting Information

\title{
Improving the Fill Factor of Perovskite Solar \\ Cells by Employing an Amine-tethered Diketopyrrolopyrrole Based Polymer as the Dopant-Free Hole Transport Layer
}

Wenbo Liu, a, b广 Yiming Ma, ${ }^{c, d \dagger}$ Zongrui Wang, ${ }^{a}$ Mu Zhu, ${ }^{e}$ Jiandong Wang, ${ }^{c}$ Maria Khalil, ${ }^{c}$ Hongyu Wang, ${ }^{d}$ Weibo Gao, ${ }^{e}$ W. J. Fan, ${ }^{* b}$ Wei-Shi Li*c and Qichun Zhang*a,e

aSchool of Materials Science and Engineering, Nanyang Technological University, 50 Nanyang Avenue, Singapore 639798. Email: qczhang@ntu.edu.sg

bSchool of Electrical and Electronic Engineering, Nanyang Technological University, 50 Nanyang Avenue, Singapore 639798. Email:

EWJFan@ntu.edu.sg

CKey Laboratory of Synthetic and Self-Assembly Chemistry for Organic Functional Molecules, Shanghai Institute of Organic Chemistry, Chinese Academy of Sciences, 345 Lingling Road, Shanghai 200032, P. R. China. Email: liws@mail.sioc.ac.cn 
dDepartment of Chemistry, College of Science, Shanghai University,99

Shangda Road, Shanghai 200444, P. R. China

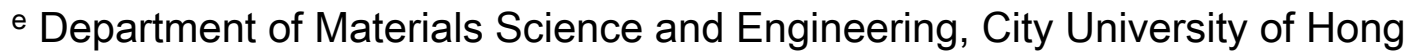

Kong, Kowloon, Hong Kong SAR, China. Email: qiczhang@cityu.edu.hk.

\section{Content}

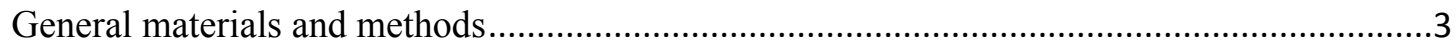

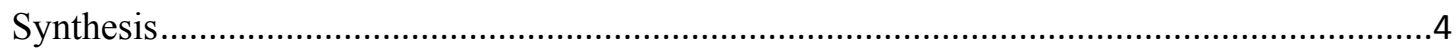

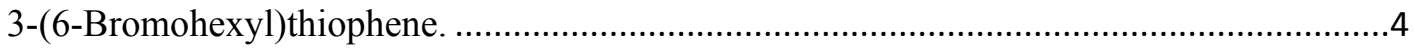

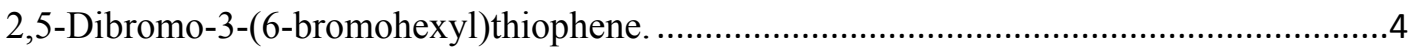

2-(6-(2,5-Dibromothiophen-3-yl)hexyl)isoindoline-1,3-dione (M3) .................................4

P25PTI.

P25NH.

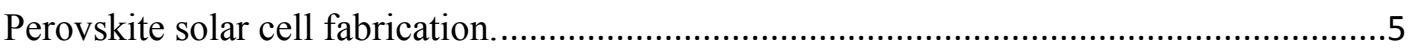

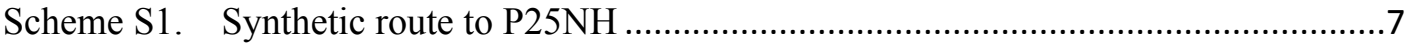

Figure S1. ${ }^{1} \mathrm{H}$ NMR of P25PTI and P25NH in 1,1,2,2-tetrachloroethane- $d_{2}$ at $80{ }^{\circ} \mathrm{C} \ldots \ldots \ldots . . .7$

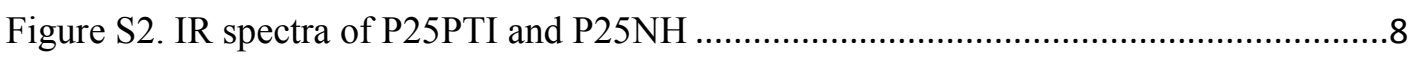

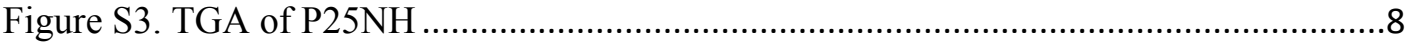

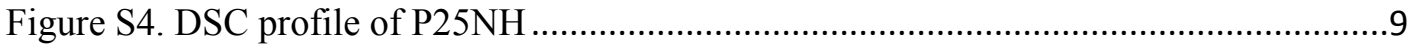

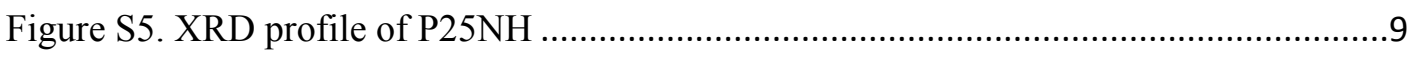

Figure S6. UV-Vis absorption spectra of P25NH in solution and film states .....................10

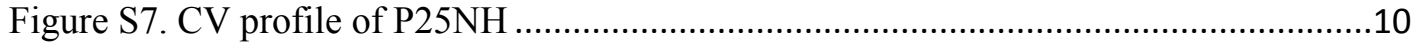

Table S1 A summary of synthesized dopant-free polymeric HTLs ...................................11

Figure S8 Photogenerated carrier movement of P25NH-based PSCs(a) and P3HT-based $\operatorname{PSCs}(\mathrm{b})$ 
Figure S9. Top view(a) and side view(c) of 3D AFM images of edge of P25NH film. (b) 2D AFM image of edge of P25NH film. (d) cross-sectional curve of P25NH film extracted from the 3D AFM image of P25NH film..

Figure S10. J-V curves of PSCs based on P25NH HTL under the concentration $6 \mathrm{mg} / \mathrm{ml} . .13$ Table S2 Performance of PSCs based on P25NH HTL under the concentration $6 \mathrm{mg} / \mathrm{ml}$...14

Figure S11. EIS characterization of PSCs with P25NH and P3HT ..................................14

Table S3. Stimulated data of EIS of solar cells based on P25NH and P3HT......................15

Table S5. The results of simulated TRPL curve. The fitted equation is $\boldsymbol{y} \equiv \underline{\boldsymbol{y}} \underline{\mathbf{0}} \pm \underline{\boldsymbol{A}} \underline{\mathbf{e}}: \underline{\boldsymbol{e}}$

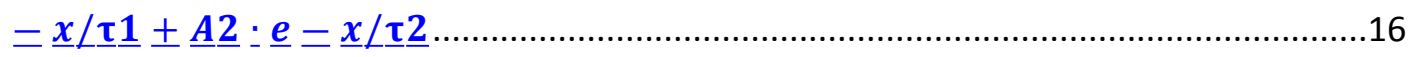

Figure S12. Stability test of PSCs with P3HT under the concentration of $16 \mathrm{mg} / \mathrm{ml}$...........16

\section{General materials and methods}

All purchased reagents were used as received. All reactions were carried out under argon atmosphere and all used solvents were dehydrated following standard methods. ${ }^{1} \mathrm{H}$ NMR (400 $\mathrm{MHz}$ ) was recorded on a Varian Mercury spectrometer with tetramethylsilane (TMS) as an internal reference. Elemental analysis on carbon, hydrogen and nitrogen contents of samples was carried out on an Elementar vario EL III elemental analyzer. Fourier Transform Infrared Spectra (FTIR) were recorded on a Nicolet AVATAR-360 Fourier transform infrared spectrophotometer. Thermogravimetric analysis (TGA) was carried out on a TGA Q500 instrument with a heating rate of $10{ }^{\circ} \mathrm{C} \min ^{-1}$ under nitrogen atmosphere. Differential scanning calorimetry (DSC) was performed on a Q2000 modulated DSC instrument with a heating rate of $10{ }^{\circ} \mathrm{C} \min ^{-1}$ and a cooling rate of $15{ }^{\circ} \mathrm{C} \mathrm{min}-1$ under nitrogen atmosphere. UV-Vis absorption spectroscopy was performed on the Hitachi U-3310 spectrophotometer. Cyclic voltammetry (CV) measurements were conducted on a $\mathrm{CHI} 660 \mathrm{C}$ instrument with a three-electrode cell using glass carbon as working electrode, platinum wire as counter electrode, and $\mathrm{Ag} / \mathrm{AgNO}_{3}$ as reference electrode in acetonitrile containing $0.1 \mathrm{M} \mathrm{Bu}_{4} \mathrm{NPF}_{6}$ electrolyte at a scan rate of $50 \mathrm{mV} \mathrm{s}^{-1}$. All samples were prepared by casting their chlorobenzene solutions onto glass carbon electrodes. The average molecular weight and polydispersity of polymers were estimated by high-temperature gel permeation chromatography (GPC) operating at $80{ }^{\circ} \mathrm{C}$ using $o$-dichlorobenzene as an eluent and monodispersed polystyrenes as standards. X-ray 
diffraction (XRD) was carried out on a PANalytical X'Pert Pro diffractometer with $\mathrm{Cu} \mathrm{K} \alpha$ beam $(40 \mathrm{kV}, 40 \mathrm{~mA})$ in $\theta-2 \theta$ scans $(0.026 \AA$ step size, $50 \mathrm{~s} / \mathrm{step})$. The XRD measurements of perovskite layers and HTLs with perovskite substrate were realized by D8 advanced with $\mathrm{CuK} \alpha$ radiation $(\lambda=0.15418 \mathrm{~nm}$ operated at $40 \mathrm{kV}$ and $30 \mathrm{~mA})$. The surface morphology of perovskite film was investigated by AFM (AFM Asylum Research Cypher S). The absorption spectra of the perovskite layer were characterized on UV-vis spectroscopy (UV-vis-NIR, Lambda 900, Perkin Elmer). The PL characteristics were measured on Cary Eclipse Fluorescence Spectrophotometer (Agilent Technologies). The perovskite films were stored in the glovebox before measurements. The measurement of PL spectra was processed in ambient condition. The excited wavelength was $532 \mathrm{~nm}$, the scan scope was $700 \mathrm{~nm}-850 \mathrm{~nm}$, the scan rate was $600 \mathrm{~nm} / \mathrm{min}$, the averaging time was $0.1 \mathrm{~s}$, and scan step was $1 \mathrm{~nm}$.

\section{Synthesis}

3-(6-Bromohexyl)thiophene. 3-Bromothiophene (17.4 g, $0.107 \mathrm{~mol})$ was dissolved in hexane (200 $\mathrm{mL}$ ), and the resulted solution was cooled to $-70{ }^{\circ} \mathrm{C}$. Then, n-BuLi (40.5 ml, $\left.2.5 \mathrm{M}, 0.1014 \mathrm{~mol}\right)$ was added dropwise, and the solution was stirred for $10 \mathrm{~min}$. After that, THF $(20 \mathrm{~mL})$ was added dropwise via a syringe until the white 3-lithiothiophene salt precipitated. After the solution was kept stirring for $1 \mathrm{~h}$, the supernate was removed and the dried hexane/THF (v/v 10/1, $220 \mathrm{ml}$ ) containing 1,6-dibromohexane (164 ml, $1.067 \mathrm{~mol})$ were successively added. After further stirred at room temperature for $2 \mathrm{~h}$, the reaction mixture was extracted with $\mathrm{CH}_{2} \mathrm{Cl}_{2}$ and washed with water $(3 \times 200 \mathrm{~mL})$. The obtained organic layer was dried over anhydrous $\mathrm{Na}_{2} \mathrm{SO}_{4}$, filtered, and concentrated. Distillation at $90{ }^{\circ} \mathrm{C}$ with oil pump gave a colorless oil, which was further purified via silica gel column chromatography using petroleum ether as the eluent. Finally, $16.04 \mathrm{~g}$ product was obtained as colorless oil in $32 \%$ yield. ${ }^{1} \mathrm{H}$ NMR (ppm, $\mathrm{CDCl}_{3}$ ): 7.25 (dd, $J=5.1,3.3 \mathrm{~Hz}, 1 \mathrm{H}$ ), $6.93(\mathrm{~m}, 2 \mathrm{H}), 3.42(\mathrm{t}, J=6.8 \mathrm{~Hz}, 2 \mathrm{H}), 2.64(\mathrm{t}, J=7.7 \mathrm{~Hz}, 2 \mathrm{H}), 1.86(\mathrm{~m}, 2 \mathrm{H}), 1.63(\mathrm{~m}, 2 \mathrm{H}), 1.41$ $(\mathrm{m}, 2 \mathrm{H}), 1.2(\mathrm{~m}, 2 \mathrm{H})$.

2,5-Dibromo-3-(6-bromohexyl)thiophene. After 3-(6-bromohexyl)thiophene (1.8796 g, 7.6 mmol) was dissolved in THF/HOAc $(30 \mathrm{ml} / 30 \mathrm{ml})$, N-bromosuccinimide $(2.842 \mathrm{~g}, 15.97 \mathrm{mmol})$ was added. After stirred overnight in dark, the reaction mixture was added with water and extracted 
with ethyl acetate. The organic phase was subsequently washed with saturated $\mathrm{NaHCO}_{3}$ solution, $\mathrm{NaOH}(5 \mathrm{w} \%)$ and brine, and dried over anhydrous $\mathrm{Na}_{2} \mathrm{SO}_{4}$. After filtration and the removal of organic solvent, the resulted residue was subjected to silica gel column chromatography using petroleum ether as eluent, colorless oil (2.84 g) was obtained in a yield of $92 \% .{ }^{1} \mathrm{H}$ NMR (ppm, $\left.\mathrm{CDCl}_{3}\right): 6.77(\mathrm{~s}, 1 \mathrm{H}), 3.41(\mathrm{t}, J=6.8 \mathrm{~Hz}, 2 \mathrm{H}), 2.52(\mathrm{t}, J=7.6 \mathrm{~Hz}, 2 \mathrm{H}), 1.86(\mathrm{~m}, 2 \mathrm{H}), 1.6-1.2(\mathrm{~m}$, $6 \mathrm{H})$.

2-(6-(2,5-Dibromothiophen-3-yl)hexyl)isoindoline-1,3-dione (M3). The solution of 3 (1.01 g, 2.5 mmol) and potassium phthalimide $(0.648 \mathrm{~g}, 3.5 \mathrm{mmol})$ in $20 \mathrm{~mL}$ DMF was stirred overnight at 80 ${ }^{\circ} \mathrm{C}$. After evaporating DMF at $90{ }^{\circ} \mathrm{C}$ under reduced pressure, the as-obtained white crude product was further purified by silica gel column chromatography using petroleum ether/ $\mathrm{CH}_{2} \mathrm{Cl}_{2}(1: 1)$ as eluent. Finally, $1.078 \mathrm{~g}$ pure product was obtained as white solid in a yield of $92 \%$. ${ }^{1} \mathrm{H}$ NMR (ppm, $\left.\mathrm{CDCl}_{3}\right): 7.84(\mathrm{dd}, J=5.4,3.0 \mathrm{~Hz}, 2 \mathrm{H}), 7.71(\mathrm{dd}, J=13.0,5.7 \mathrm{~Hz}, 2 \mathrm{H}), 6.76(\mathrm{~s}, 1 \mathrm{H}), 3.68$ (t, $J=7.2 \mathrm{~Hz}, 2 \mathrm{H}), 2.49(\mathrm{t}, J=7.6 \mathrm{~Hz}, 2 \mathrm{H}), 1.68(\mathrm{~m}, 2 \mathrm{H}), 1.6-1.3(\mathrm{~m}, 6 \mathrm{H})$.

P25PTI. To an argon-bubbled solution of 3,6-bis(5-bromothiophen-2-yl)-2,5-bis(2-hexyldecyl) pyrrolo[3,4-c]pyrrole-1,4(2H,5H)-dione (M1, $272.1 \mathrm{mg}, 0.3 \mathrm{mmol}), 2,5$-bis(trimethylstannyl) thiophene (M2, $163.9 \mathrm{mg}, 400 \mu \mathrm{mol})$, and $\mathbf{M 3}(47.1 \mathrm{mg}, 100 \mathrm{mmol})$ in toluene $(5 \mathrm{ml})$, a mixture of tris(dibenzylideneacetone)dipalladium $(1.83 \mathrm{mg}, 0.002 \mathrm{mmol})$ and tri-o-tolylphosphine $(2.43$ $\mathrm{mg}, 8 \mathrm{mmol}$ ) was added. Then, the resulted mixture was kept stirring at $80{ }^{\circ} \mathrm{C}$ for 3 days. Then 2-bromothiophene $(2 \mu \mathrm{l})$ and 2-tributylstannylthiophene $(6.35 \mu \mathrm{l})$ were successively added as end-capping agents. After precipitation with $\mathrm{MeOH}$, the crude polymer was further purified by Soxhlet extraction with methanol, hexane and $\mathrm{CHCl}_{3}$, respectively, to afford $312 \mathrm{mg}$ pure product as a green solid in a yield of $64 \% .{ }^{1} \mathrm{H}$ NMR (ppm, 1,1,2,2-tetrachloroethane- $\left.d_{4}, 80^{\circ} \mathrm{C}\right): 8.90(\mathrm{br}$, 2H), $7.84(\mathrm{~s}, 1.33 \mathrm{H}), 7.72(\mathrm{~s}, 1.33 \mathrm{H}), 7.3-7.0(\mathrm{~m}, 5 \mathrm{H}), 4.02(\mathrm{br}, 4 \mathrm{H}), 1.96(\mathrm{br}, 2 \mathrm{H}), 1.64-1.00(\mathrm{~m}$, $50 \mathrm{H}), 0.98-0.61(\mathrm{~m}, 12 \mathrm{H}) . \quad \mathrm{GPC}\left(o-\mathrm{DCB}, 80^{\circ} \mathrm{C}\right): M_{\mathrm{n}}=29.6 \mathrm{kDa}, \mathrm{PDI}=3.17$

P25NH. A solution of P25PTI (116 mg, $0.095 \mathrm{mmol}), \mathrm{N}_{2} \mathrm{H}_{4} \cdot \mathrm{H}_{2} \mathrm{O}(2 \mathrm{ml}$ ), $\mathrm{MeOH}(2 \mathrm{ml})$, and toluene $(30 \mathrm{ml})$ was stirred at $80{ }^{\circ} \mathrm{C}$ overnight. Then, the as-obtained polymer was precipitated in methanol, and purified by Soxhlet extraction with methanol, hexane and $\mathrm{CHCl}_{3}$, respectively, to 
afford $90 \mathrm{mg}$ P25NH as a green solid in a yield of $71 \%$. ${ }^{1} \mathrm{H}$ NMR (ppm, 1,1,2,2-tetrachloroethane- $\left.d_{4}, 80^{\circ} \mathrm{C}\right): 8.83(\mathrm{br}, 2 \mathrm{H}), 7.3-7.0(\mathrm{~m}, 5 \mathrm{H}), 4.03(\mathrm{br}, 4 \mathrm{H}), 2.00(\mathrm{br}, 2 \mathrm{H})$, $1.8-1.1(\mathrm{~m}, 50 \mathrm{H}), 1.1-0.8(\mathrm{~m}, 12 \mathrm{H}) . \mathrm{GPC}\left(o-\mathrm{DCB}, 80{ }^{\circ} \mathrm{C}\right): M_{\mathrm{n}}=33.0 \mathrm{kDa}, \mathrm{PDI}=4.64$.

Perovskite solar cell fabrication. The ITO-coated glass substrates were cleaned successively with Decon 90 (detergent) diluted solution, deionized water, acetone, isopropanol and ethanol in an ultrasonic bath for $20 \mathrm{~min}$, respectively, and dried with nitrogen gas. An electron transport layer (ETL) of $\mathrm{SnO}_{2} / \mathrm{H}_{2} \mathrm{O}(1: 5, \mathrm{v} / \mathrm{v})$ was spin-coated onto cleaned ITO transparent glass substrates at $6000 \mathrm{rpm}$ for $60 \mathrm{~s}$ in ambient condition and annealed at $150{ }^{\circ} \mathrm{C}$ for $30 \mathrm{~min}$. The perovskite films were deposited using a single-step deposition method from the precursor solution containing FAI (0.26 M), $\mathrm{PbI}_{2}(1.26 \mathrm{M}), \mathrm{MAI}(1.08 \mathrm{M})$ and $\mathrm{PbCl}_{2}(0.14 \mathrm{M})$ in $\mathrm{DMSO} / \mathrm{GBL}(3: 7, \mathrm{v} / \mathrm{v})$. The precursor solution was spin-coated onto the surface of $\mathrm{SnO}_{2}$ layers in a two-step method at 1200 and $4300 \mathrm{rpm}$ for 18 and $60 \mathrm{~s}$, respectively. During the second step, $600 \mu \mathrm{l}$ of toluene was dropped on the spinning substrate $30 \mathrm{~s}$ prior to the end of the spin coating. After spin coating of precursor solution, the substrates were transferred to hot plate and heated at $105{ }^{\circ} \mathrm{C}$ for $30 \mathrm{~min}$. Hole transport materials (HTM) in DCB solution with different concentration were spun at $2000 \mathrm{rpm}$ for $60 \mathrm{~s}$, and immediately heat-treated at $100{ }^{\circ} \mathrm{C}$ for $10 \mathrm{~min}$. Finally, about $100 \mathrm{~nm}$ silver was deposited on the surface of hole transport layer (HTL) through high temperature vacuum evaporation. 

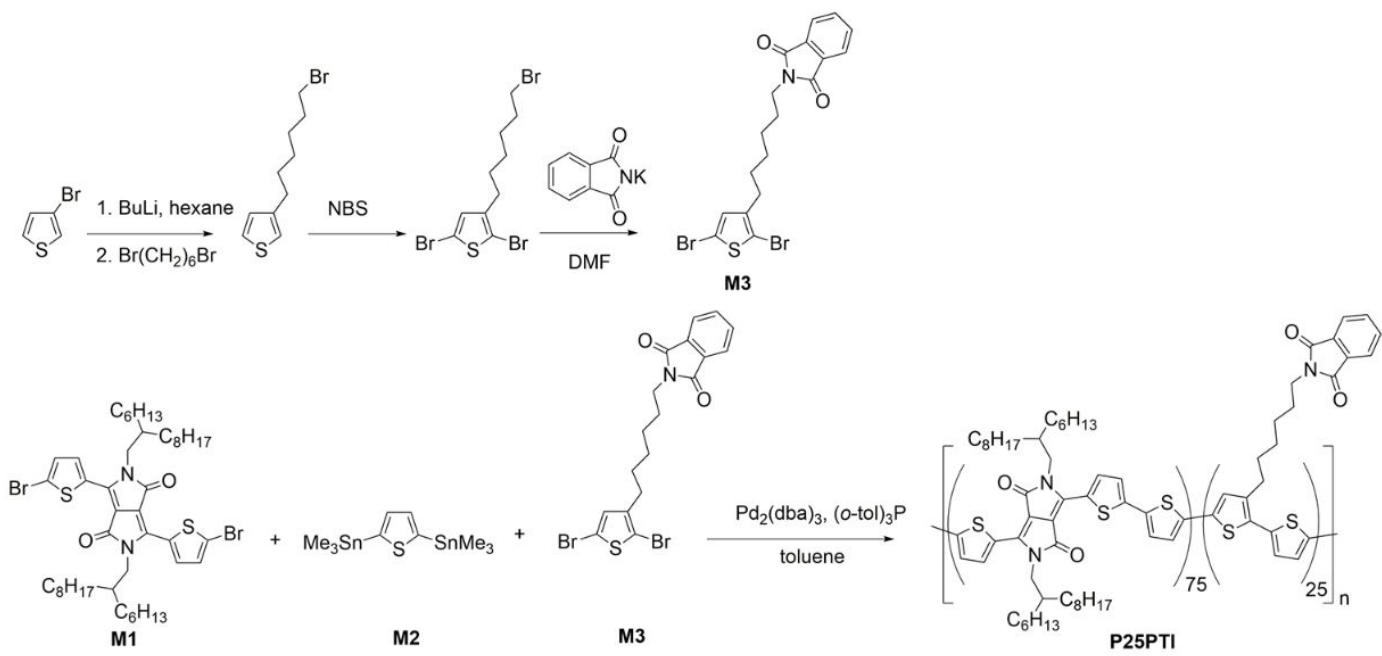

Feeding molar ratio: $\mathbf{M 1}: \mathbf{M} 2: \mathbf{M} 3=75: 100: 25$

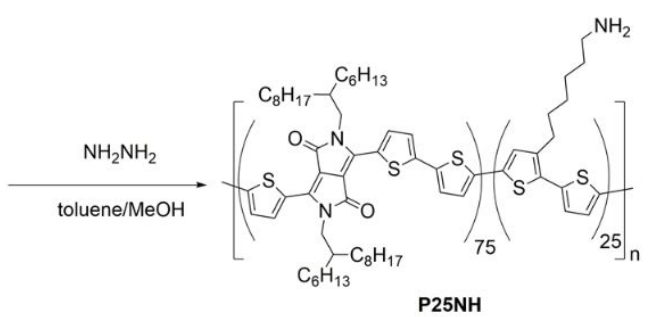

Scheme S1. Synthetic route to P25NH 


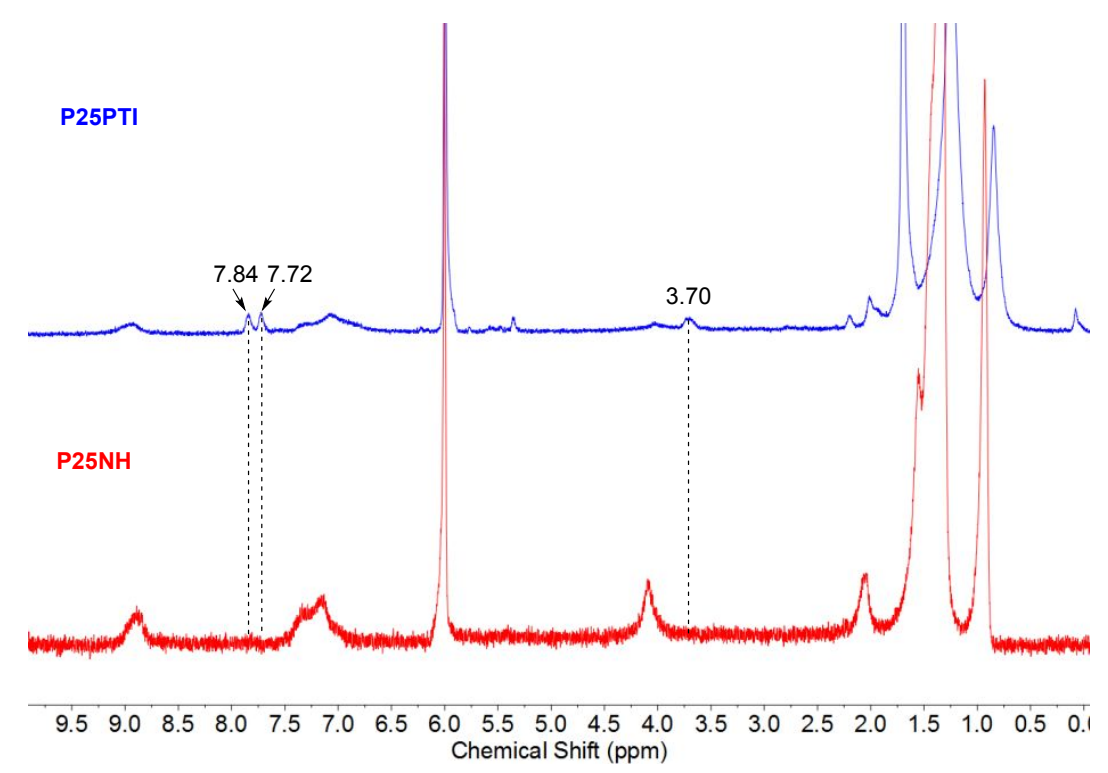

Figure S1. ${ }^{1} \mathrm{H}$ NMR of P25PTI and P25NH in 1,1,2,2-tetrachloroethane- $d_{2}$ at $80{ }^{\circ} \mathrm{C}$

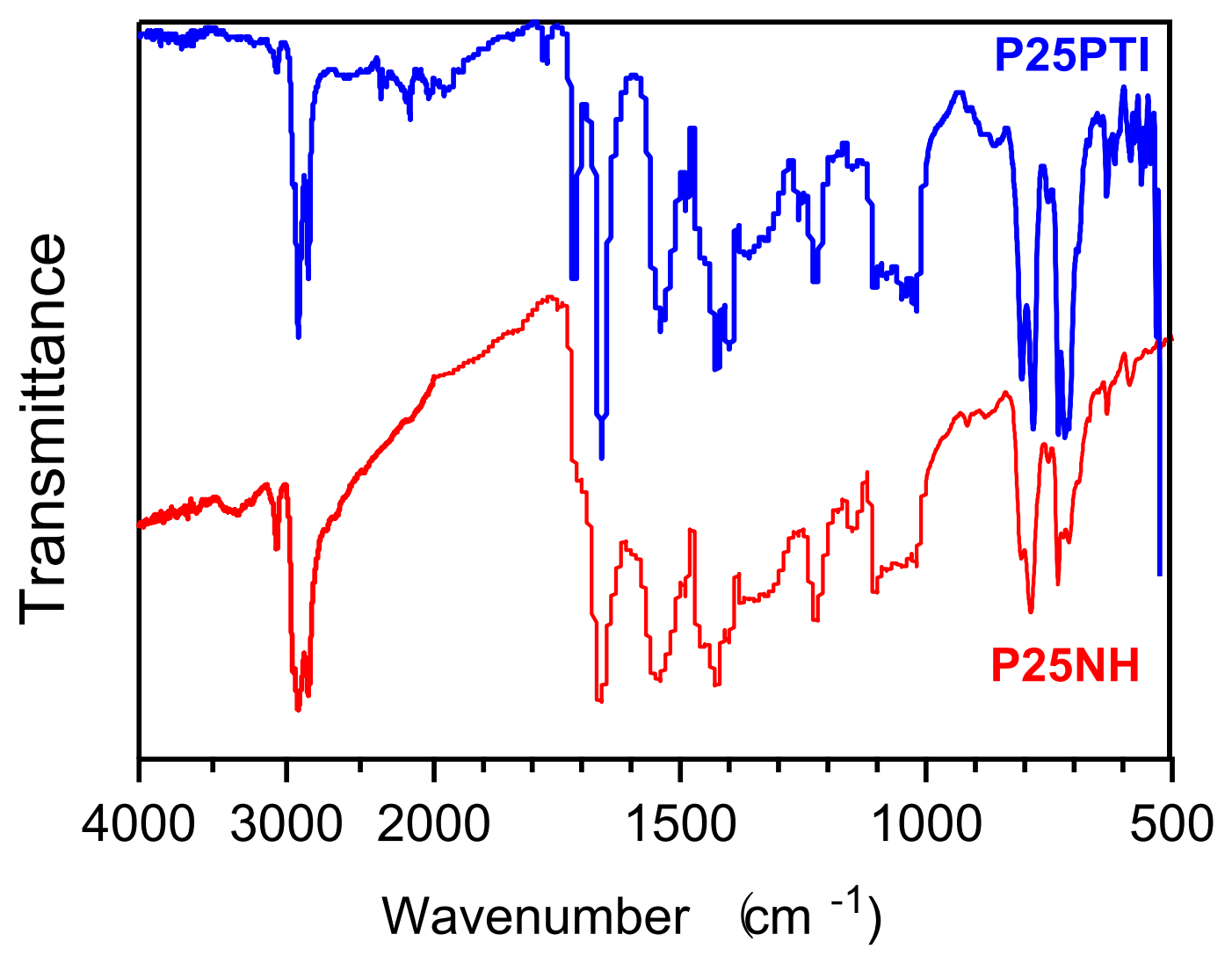

Figure S2. IR spectra of P25PTI and P25NH 


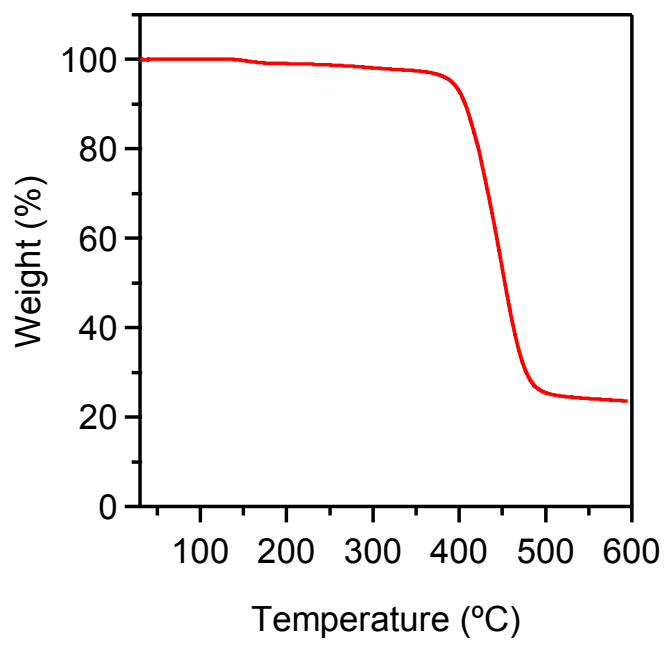

Figure S3. TGA of P25NH

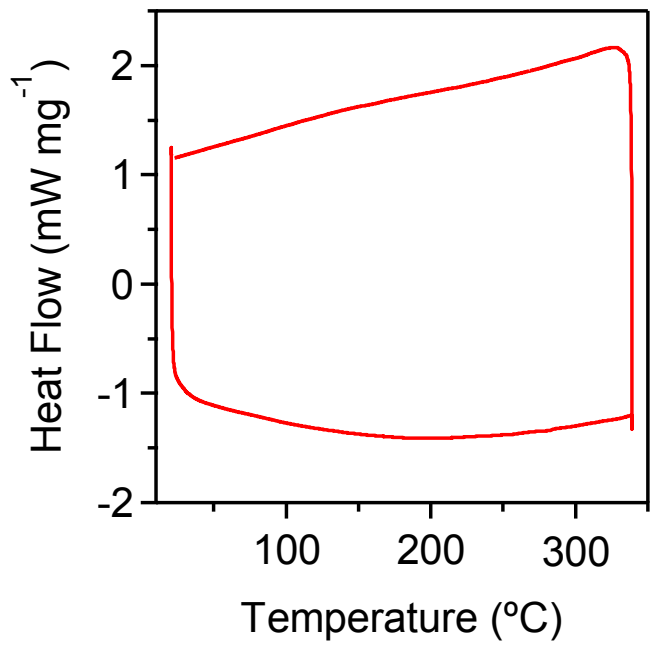

Figure S4. DSC profile of P25NH 


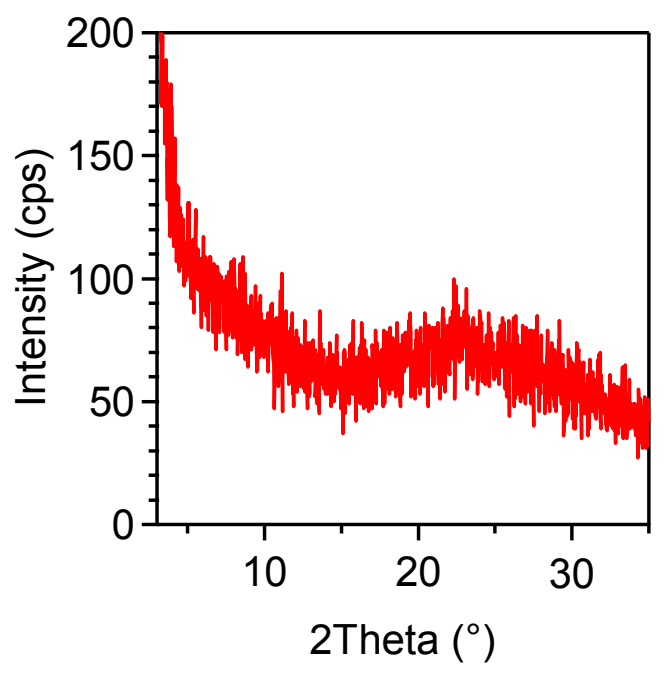

Figure S5. XRD profile of $\mathrm{P} 25 \mathrm{NH}$

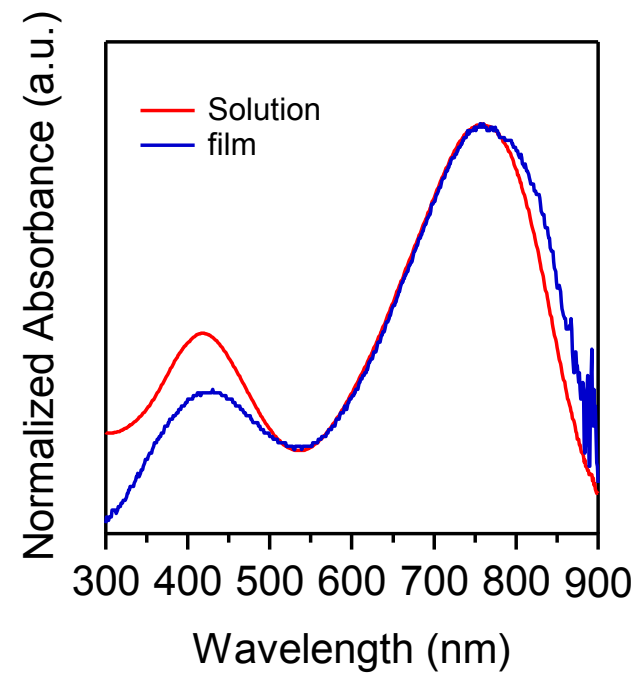

Figure S6. UV-Vis absorption spectra of P25NH in solution and film states 


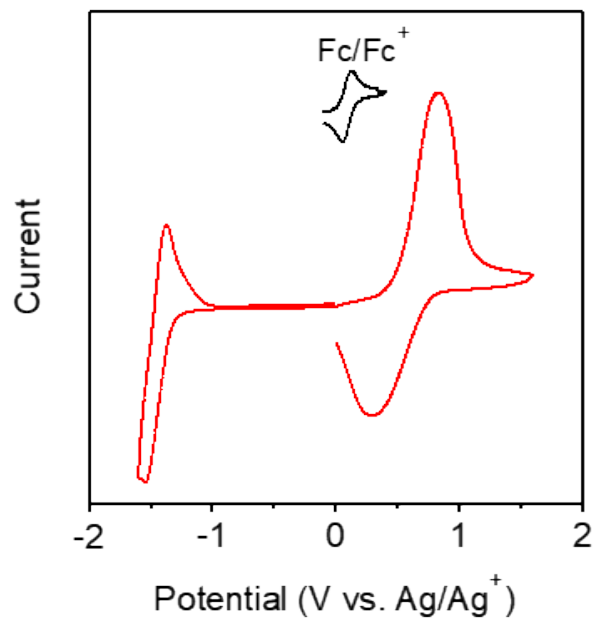

Figure S7. CV profile of $\mathrm{P} 25 \mathrm{NH}$

Table S1 A summary of synthesized dopant-free polymeric HTLs

\begin{tabular}{|c|c|c|}
\hline Reference & Structure & $\begin{array}{c}\text { Highest Fill } \\
\text { factor(\%) }\end{array}$ \\
\hline $\begin{array}{l}\text { November } \\
2018[1]\end{array}$ & ITO/NiO ${ }_{x} /$ perovskite/PN-F25\%/Ag & 71.8 \\
\hline April 2019[2] & $\begin{array}{l}\mathrm{FTO} / \mathrm{TiO}_{2} / \mathrm{PCBA} /\left(\mathrm{FAPbI}_{3}\right)_{0.85} \\
\quad\left(\mathrm{MAPbBr}_{3}\right)_{0.15} / \mathrm{P} 1 / \mathrm{Au}\end{array}$ & 76.7 \\
\hline April 2019[3] & ITO/C $60 /$ perovskite $/ \mathrm{FBA} 3 / \mathrm{MoO}_{3} / \mathrm{Ag}$ & 79.9 \\
\hline May $2019^{[4]}$ & $\begin{array}{c}\mathrm{FTO} / \mathrm{SnO}_{2} / \mathrm{Cs}_{0.05} \mathrm{FA}_{0.81} \mathrm{MA}_{0.14} \mathrm{PbI}_{2.55} \mathrm{Br}_{0.45} / \mathrm{P} 2 / \\
\mathrm{Au}\end{array}$ & 72.7 \\
\hline June $2019^{[5]}$ & $\begin{array}{c}\mathrm{FTO} / \mathrm{c}-\mathrm{TiO}_{2} / \mathrm{m}_{-}-\mathrm{TiO}_{2} / \mathrm{Cs}_{0.05} \mathrm{FA}_{0.81} \mathrm{MA}_{0.14} \mathrm{PbI}_{2.55} \mathrm{Br}_{0.45} / \mathrm{DTB}(\mathrm{xDEG} \\
) / \mathrm{Au}\end{array}$ & 75.08 \\
\hline
\end{tabular}




\begin{tabular}{|c|c|c|}
\hline July $2019^{[6]}$ & $\mathrm{FTO} / \mathrm{TiO}_{2} / \mathrm{PCBA} /$ Perovskite/PDTITT/Au & 75 \\
\hline August $2019^{[7]}$ & $\begin{array}{c}\mathrm{FTO} / \text { Compact- } \mathrm{TiO}_{2} / \\
\text { Mesoporous- } \mathrm{TiO}_{2} / \text { Perovskite/PBT1-C } / \mathrm{MoO}_{3} / \mathrm{Ag}\end{array}$ & 81.22 \\
\hline August $2019^{[8]}$ & $\mathrm{FTO} / \mathrm{SnO}_{2} /$ perovskite/2-MA/Au & 79.8 \\
\hline August 2019[9] & $\mathrm{FTO} / \mathrm{SnO}_{2} /$ perovskite/P3/Au & 80 \\
\hline $\begin{array}{l}\text { September } \\
2019^{[10]}\end{array}$ & $\begin{array}{c}\mathrm{ITO} / \mathrm{SnO}_{2}(20 \mathrm{~nm}) / \mathrm{PCBA}-\left(\mathrm{FAPbI}_{3}\right)_{\mathrm{x}}\left(\mathrm{MAPbBr}_{3}\right)_{1} \mathrm{x}(600 \mathrm{~nm}) / \mathrm{P}-\mathrm{Si} \\
/ \mathrm{Au}\end{array}$ & 77 \\
\hline $\begin{array}{l}\text { September } \\
2019^{[11]}\end{array}$ & ITO $/ \mathrm{SnO}_{2} /$ perovskite $/ \mathrm{PBDTT} / \mathrm{MoO}_{3} / \mathrm{Ag}$ & 76.67 \\
\hline $\begin{array}{l}\text { October } \\
2019^{[12]}\end{array}$ & $\mathrm{FTO} / \mathrm{SnO}_{2} /$ Perovskite $/ \mathrm{PBDT}[2 \mathrm{~F}] \mathrm{T} / \mathrm{Ag}$ & 72.60 \\
\hline This work & $\mathrm{ITO} / \mathrm{SnO}_{2} /$ perovskite/P25NH/Ag & $\begin{array}{l}81.9(1.6 \mathrm{mg} / \mathrm{ml}) \\
/ 83.2(6 \mathrm{mg} / \mathrm{ml})\end{array}$ \\
\hline
\end{tabular}

(a)

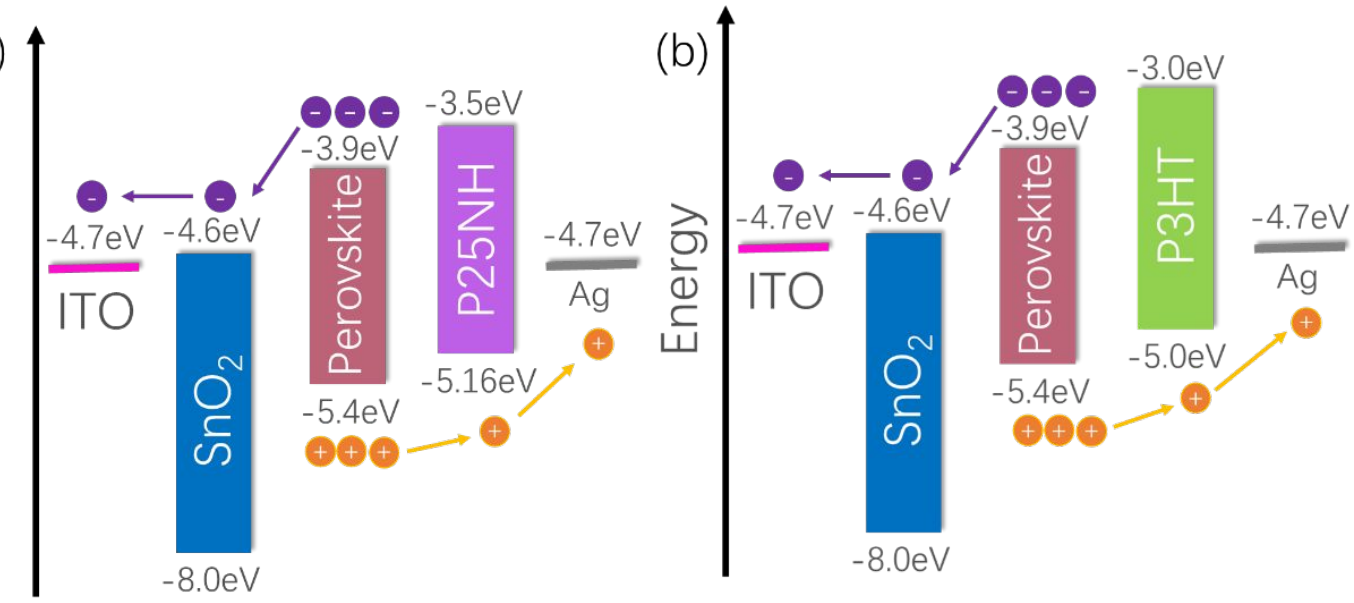

Figure S8 Photogenerated carrier movement of P25NH-based PSCs(a) and P3HT-based PSCs(b). 
(a)

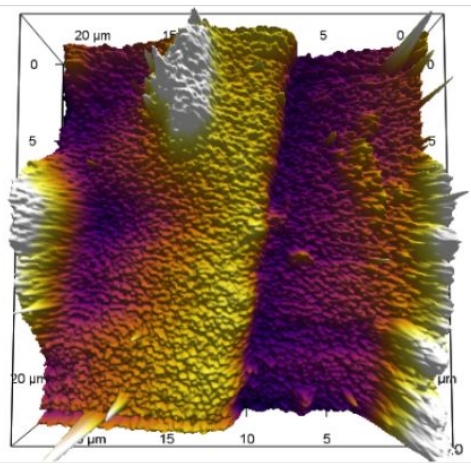

(c)

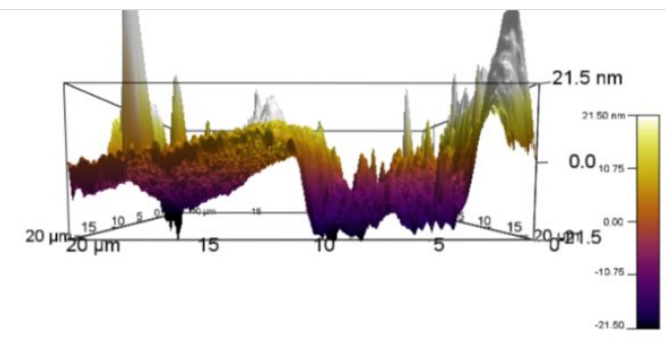

(b)
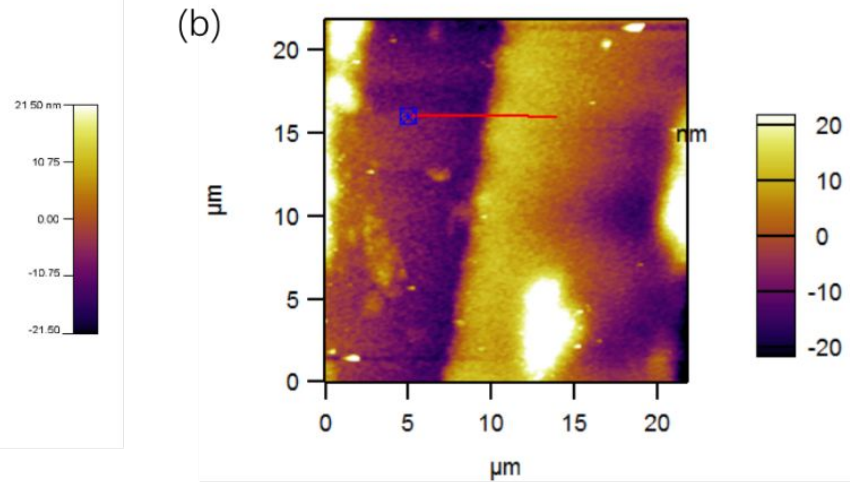

(d)

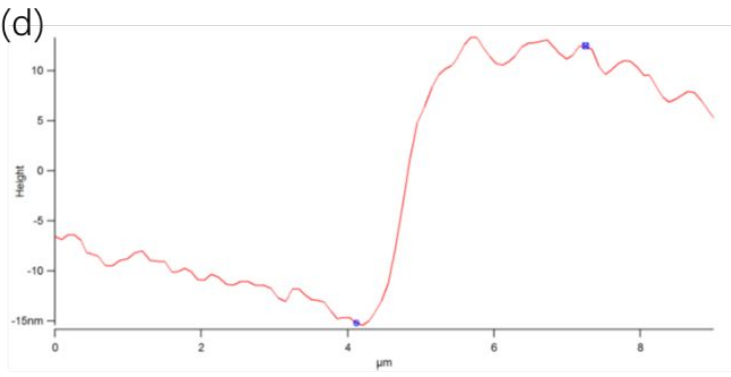

Figure S9. Top view(a) and side view(c) of 3D AFM images of edge of P25NH film. (b) 2D AFM image of edge of P25NH film. (d) cross-sectional curve of P25NH film extracted from the 3D AFM image of P25NH film.

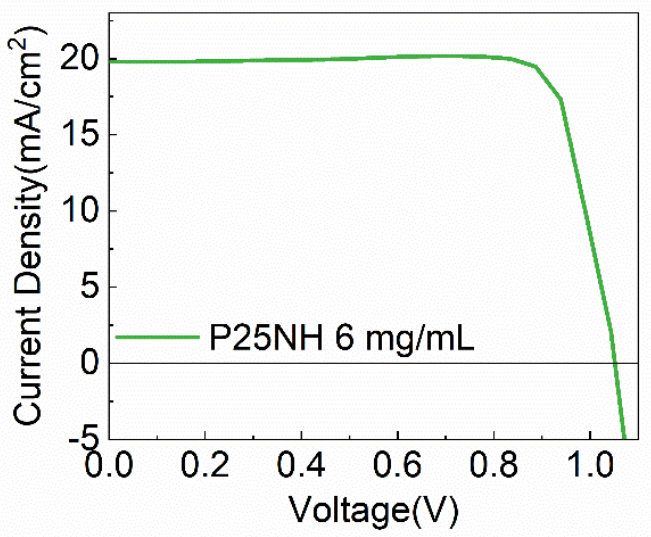

Figure S10. J-V curves of PSCs based on P25NH HTL under the concentration $6 \mathrm{mg} / \mathrm{ml}$ 
Table S2 Performance of PSCs based on P25NH HTL under the concentration $6 \mathrm{mg} / \mathrm{ml}$

\begin{tabular}{llllll}
\hline HTL & & Jsc $\left(\mathrm{mA} / \mathrm{cm}^{2}\right)$ & Voc $(\mathrm{mV})$ & Fill factor(\%) & PCE(\%) \\
\hline P25NH 6mg/ml & Aver. & 20.33 & 1025.133 & 77.75 & 16.14 \\
& Max. & 19.81 & 1049 & 83.2 & 17.3 \\
\hline
\end{tabular}

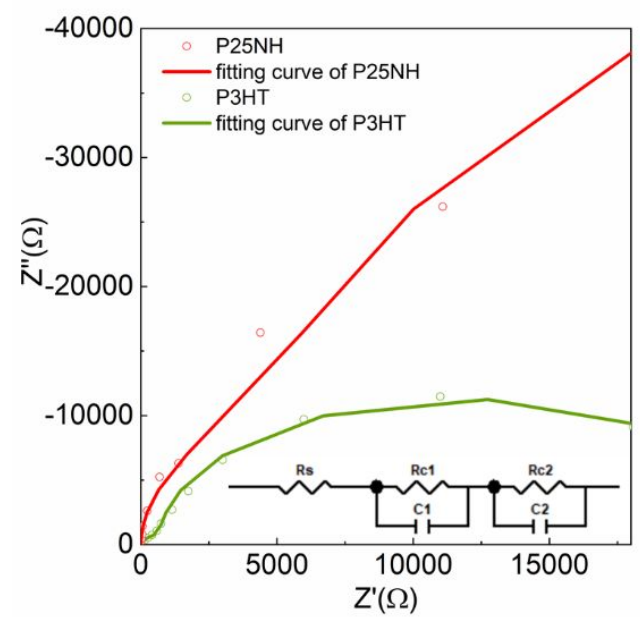

Figure S11. EIS characterization of PSCs with P25NH and P3HT as HTLs at forward bias Vappl $(0.4 \mathrm{~V})$ under dark condition. Inserted Figure is the equivalent circuit used for modelling PSCs based on $\mathrm{P} 25 \mathrm{NH}$ and $\mathrm{P} 3 \mathrm{HT}$, where $\mathrm{R} 1$ is the series resistance, $\mathrm{Rc} 1 / \mathrm{C} 1$ is the resistance/capacitance associated with the electrode. The difference in the value of Rc1 could be attributed to the disparities interface contact between the HTLs and electrodes. ${ }^{[13-15]} \mathrm{Rc} 2 / \mathrm{C} 2$ is the resistance/capacitance related to the HTL/perovskite layer interface. 
Table S3. Stimulated data of EIS of solar cells based on P25NH and P3HT as HTLs

\begin{tabular}{llllll}
\hline & $\operatorname{Rs}(\Omega)$ & $\operatorname{Rc} 1(\Omega)$ & $\operatorname{Rc} 2(\Omega)$ & $\mathrm{C} 1(\mathrm{nF})$ & $\mathrm{C} 2(\mathrm{nF})$ \\
\hline P25NH & 7.24 & 5328 & 124300 & 7 & 5.12 \\
P3HT & 27.9 & 659 & 22970 & 2.6 & 5.4 \\
\hline
\end{tabular}

Table S4. Characteristics of OFET based on P25NH as HTL

\begin{tabular}{lllll}
\hline $\begin{array}{l}\text { Temperature } \\
\left({ }^{\circ} \mathrm{C}\right)\end{array}$ & & Mobility $\left(\mathrm{cm}^{2} / \mathbf{V s}\right)$ & Ion/Ioff & Vt \\
\hline RT & Aver. & $1.93 \mathrm{E}-2$ & $10^{1}$ & 12.4 \\
& Max. & $2.10 \mathrm{E}-2$ & 26.7 & 12.0 \\
140 & Aver. & $2.57 \mathrm{E}-2$ & $10^{1}$ & 19.8 \\
& Max. & $3.01 \mathrm{E}-2$ & 51.2 & 18.8 \\
200 & Aver. & $1.74 \mathrm{E}-2$ & $10^{2}$ & 18.9 \\
& Max. & $1.82 \mathrm{E}-2$ & $2.19 \times 10^{2}$ & 21.1 \\
& & & 102 & 12.1 \\
& Aver. & $3.88 \mathrm{E}-2$ & $2.45 \times 10^{2}$ & 11.2 \\
\hline
\end{tabular}


Table S5. The results of simulated TRPL curve. The fitted equation is $\boldsymbol{y}=\boldsymbol{y}_{\mathbf{0}}+\boldsymbol{A}_{\mathbf{1}} \cdot \boldsymbol{e}^{-\boldsymbol{x} / \boldsymbol{\tau}_{1}}+\boldsymbol{A}_{\mathbf{2}}$. $e^{-x / \tau_{2}}$

\begin{tabular}{|c|c|c|c|c|c|}
\hline & $\mathrm{y}_{0}$ & $\mathrm{~A}_{1}$ & $\tau_{1}$ & $\mathrm{~A}_{2}$ & $\tau_{2}$ \\
\hline Perovskite & $\begin{array}{l}0.06225 \quad \pm \\
0.00476\end{array}$ & $\begin{array}{l}135657.83435 \\
\pm 49128.3307\end{array}$ & $\begin{array}{l}18.04097 \\
\pm 0.49319\end{array}$ & $\begin{array}{l}2.29014 \quad \pm \\
0.04906\end{array}$ & $\begin{array}{l}185.84071 \\
\pm 3.4271\end{array}$ \\
\hline Perovskite/P25NH & $\begin{array}{l}0.02447 \quad \pm \\
4.52369 \mathrm{E}-4\end{array}$ & $\begin{array}{l}3.31034 \mathrm{E} 13 \quad \pm \\
6.64121 \mathrm{E} 12\end{array}$ & $\begin{array}{l}7.58359 \pm \\
0.04736\end{array}$ & $\begin{array}{l}1525.62057 \\
\pm 60.93029\end{array}$ & $\begin{array}{l}25.58343 \pm \\
0.09209\end{array}$ \\
\hline Perovskite/P3HT & $\begin{array}{l}0.0118 \quad \pm \\
3.81468 \mathrm{E}-4\end{array}$ & $\begin{array}{l}9.42753 \mathrm{E} 16 \quad \pm \\
1.4514 \mathrm{E} 16\end{array}$ & $\begin{array}{l}6.08747 \pm \\
0.02345\end{array}$ & $\begin{array}{l}1.47543 \mathrm{E} 11 \\
\pm \\
5.75048 \mathrm{E} 10\end{array}$ & $\begin{array}{l}8.98173 \pm \\
0.11308\end{array}$ \\
\hline
\end{tabular}

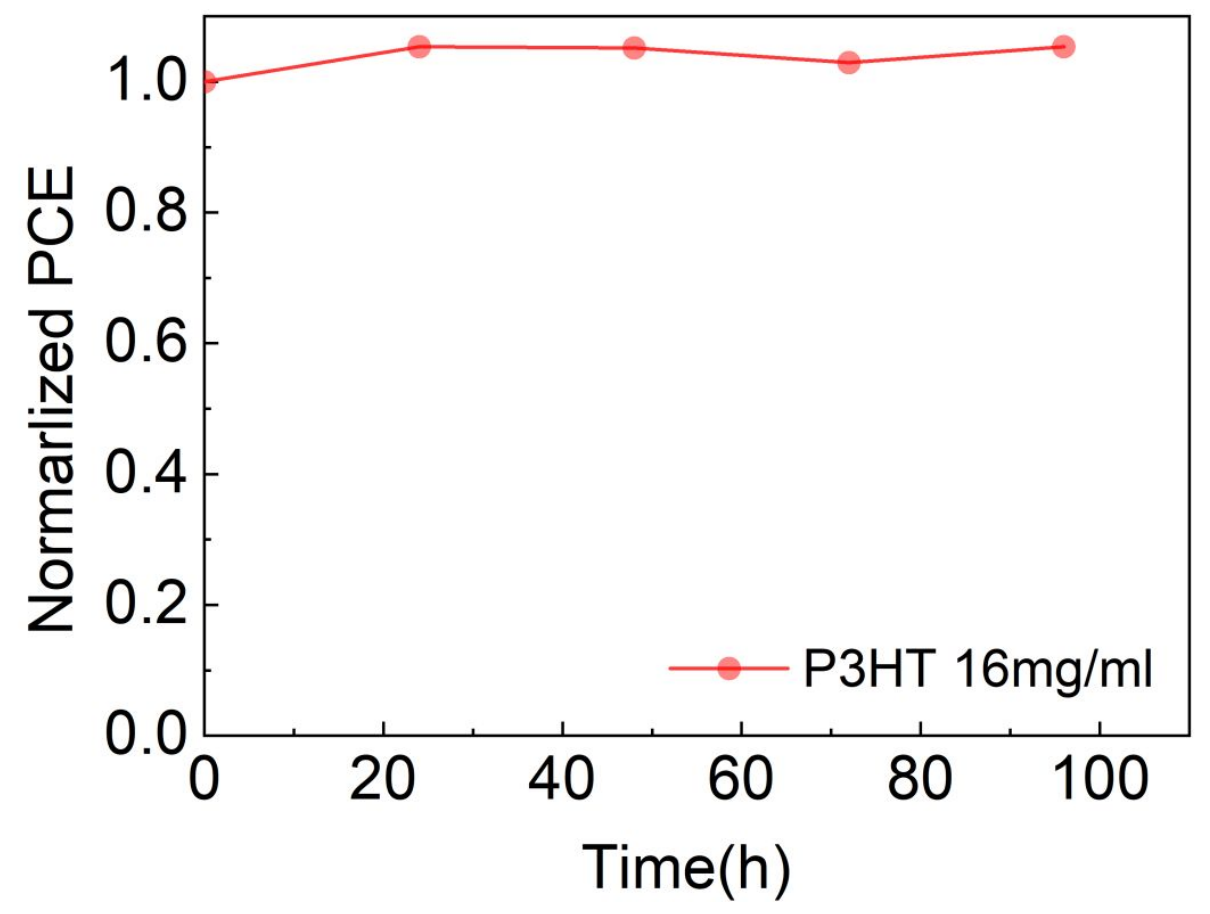

Figure S12. Stability test of PSCs with P3HT as HTL with the concentration of $16 \mathrm{mg} / \mathrm{ml}$ 


\section{References:}

[1] Tian, L.; Hu, Z.; Liu, X.; Liu, Z.; Guo, P.; Xu, B.; Xue, Q.; Yip, H. Huang, F.; Cao, Y. Fluoroand Amino-Functionalized Conjugated Polymers as Electron Transport Materials for Perovskite Solar Cells with Improved Efficiency and Stability. ACS Appl. Mater. Interfaces 2019, 11, 5289-5297

[2] Zhang, L.; Wu, J.; Li, D.; Li, W.; Meng, Q.; Bo, Z. Ladder-like conjugated polymers used as hole-transporting materials for high-efficiency perovskite solar cells. J. Mater. Chem. A 2019, 7, 14473.

[3] Sun, X.; Wu, F.; Zhong, C.; Zhu L.; Li. Z. A structure-property study of fluoranthene-cored hole-transporting materials enables $19.3 \%$ efficiency in dopant-free perovskite solar cells. Chem. Sci., 2019, 10, 6899.

[4] Wu, J.; Liu, C.; Li, B.; Gu, F.; Zhang, L.; Hu, M.; Deng, X.; Qiao, Y.; Mao, Y.; Tan, W.; Tian, Y. ; Xu, B. Side-Chain Polymers as Dopant-Free Hole-Transporting Materials for Perovskite Solar Cells-The Impact of Substituents' Positions in Carbazole on Device Performance. ACS Appl. Mater. Interfaces 2019, 11, 26928.

[5] Zhang, L.; Liu, C.; Wang, X.; Tian, Y.; Jen, A. K. Y.; Xu, B. Side-Chain Engineering on Dopant-Free Hole-Transporting Polymers toward Highly Efficient Perovskite Solar Cells (20.19\%). Adv. Funct. Mater. 2019, 29, 1904856.

[6] Tavakoli, M.; Zhao, J.; Po, R.; Bianchi, G.; Cominetti, A.; Carbonera, C.; Kong, J. Efficient and Stable Mesoscopic Perovskite Solar Cells Using PDTITT as a New Hole Transporting Layer. Adv. Funct. Mater. 2019, 29, 1905887.

[7] Qi, F.; Deng, X.; Wu, X.; Huo, L.; Xiao, Y.; Lu, X.; Zhu, Z.; Jen, A. K.-Y. Hybrid Perovskite - Organic Flexible Tandem Solar Cell Enabling Highly Efficient Electrocatalysis Overall Water Splitting. Adv. Energy Mater. 2019, 9, 1902600.

[8] Lee, J.; Kim, G.; Kim, M.; Park, S.; Park, T. Nonaromatic Green - Solvent - Processable, Dopant - Free, and Lead - Capturable Hole Transport Polymers in Perovskite Solar Cells with High Efficiency. Adv. Energy Mater. 2020, 10, 1902662.

[9] Zhang, F.; Yao, Z.; Guo, Y.; Li, Y.; Bergstrand, J.; Brett, C. J.; Cai, B.; Hajian, A.; Guo, Y.; Yang, X.; Gardner, J.; Widengren, J.; Roth, S. V.; Kloo, L.; Sun. L. Polymeric, Cost-Effective, Dopant-Free Hole Transport Materials for Efficient and Stable Perovskite Solar Cells. J. Am. Chem. Soc. 2019, 141, 19700-19707.

[10] Yu, B.; Zhang, L.; Wu, J.; Liu, K.; Wu, H.; Shi, J.; Luo, Y.; Li, D.; Bo , Z.; Meng. Q. Application of a new $\pi$-conjugated ladder-like polymer in enhancing the stability and efficiency of perovskite solar cells. J. Mater. Chem. A, 2020, 8, 1417.

[11] You, G.; Zhuang, Q.; Wang, L.; Lin, X.; Zou, D.; Lin, Z.; Zhen, H.; Zhuang, W.; Ling, Q. Dopant - Free, Donor - Acceptor - Type Polymeric Hole - Transporting Materials for the Perovskite Solar Cells with Power Conversion Efficiencies over 20\%. Adv. Energy Mater. 2020, 10, 1903146.

[12] Kong, X.; Jiang, Y.; Wu, X.; Chen, C.; Guo, J.i; Liu, S.; Gao, X.; Zhou, G.; Liu, J.; Kempa, K.; Gao, J. Dopant-free F-substituted benzodithiophene copolymer hole-transporting materials for efficient and stable perovskite solar cells. J. Mater. Chem. A, 2020, 8, 1858.

[13] Li, J.; Li, W.; Dong, H.; Li, N.; Guo, X.; Wang, L. Enhanced Performance in Hybrid Perovskite Solar Cell by Modification with Spinel Lithium Titanate. J. Mater. Chem. A 2015, 3, 
8882-8889.

[14] Jeong, I.; Park, Y. H.; Bae, S.; Park, M.; Jeong, H.; Lee, P.; Ko, M. J. Solution-Processed Ultrathin $\mathrm{TiO}_{2}$ Compact Layer Hybridized with Mesoporous $\mathrm{TiO}_{2}$ for High-Performance Perovskite Solar Cells. ACS Appl. Mater. Interfaces 2017, 9, 36865-36874.

[15] Kim, H.-S.; Lee, J.-W.; Yantara, N.; Boix, P. P.; Kulkarni, S. A.; Mhaisalkar, S.; Graetzel, M.; Park, N.-G. High Efficiency Solid-State Sensitized Solar Cell-Based on Submicrometer Rutile $\mathrm{TiO}_{2}$ Nanorod and $\mathrm{CH}_{3} \mathrm{NH}_{3} \mathrm{PbI}_{3}$ Perovskite Sensitizer. Nano Lett. 2013, 13, 2412-2417. 